\title{
Steam sauna and mother roasting in Lao PDR: practices and chemical constituents of essential oils of plant species used in postpartum recovery
}

\author{
Hugo J de Boer ${ }^{1 *+}$, Vichith Lamxay ${ }^{1,2+}$ and Lars Björk
}

\begin{abstract}
Background: Fundamental in traditional postpartum recovery in Lao PDR is the use of hotbeds, mother roasting, steam sauna and steam baths. During these treatments medicinal plants play a crucial role, but little has been published about how the treatments are carried out precisely, which species are used, the medicinal properties of these species, and the medicinal efficacy of their chemical constituents.

Methods: Sixty-five interviews, in 15 rural villages, with women of 4 different ethnic groups were conducted to survey confinement rituals, and postpartum plant use and salience. Essential oils from the main species used were extracted using steam distillation and the main chemical constituents characterized using gas chromatographymass spectrometry (GC-MS).
\end{abstract}

Results: A total of 10 different species were used by three or more of the ethnic groups included in this study. All species were used in steam sauna and bath, but only 3 species were used in hotbed and mother roasting. Essential oils of Amomum villosum, Amomum microcarpum and Blumea balsamifera were found to contain significant amounts of the following terpenes: $\beta$-pinene, camphor, bornyl acetate, borneol, linalool, D-limonene, fenchone, terpinen-4-ol and $\alpha$-terpinene.

Conclusions: Many of these terpenes have documented antimicrobial and analgesic properties, and some have also synergistic interactions with other terpenes. The mode of application in hotbed and mother roasting differs from the documented mechanisms of action of these terpenes. Plants in these two practices are likely to serve mainly hygienic purposes, by segregating the mother from infection sources such as beds, mats, stools, cloth and towels. Steam sauna medicinal plant use through inhalation of essential oils vapors can possibly have medicinal efficacy, but is unlikely to alleviate the ailments commonly encountered during postpartum convalescence. Steam sauna medicinal plant use through dermal condensation of essential oils, and steam bath cleansing of the perineal area is possibly a pragmatic use of the reported medicinal plants, as terpene constituents have documented antimicrobial, analgesic and anti-inflammatory properties.

\section{Background}

The postpartum period is important in many Southeast Asian cultures, and is seen as a time of recovery and often entails a period of confinement ranging from 10 up to 45 days. In accordance with humoral medicine, pregnancy is seen as a hot state; with parturition heat is lost and the woman comes into a state of excess cold,

\footnotetext{
* Correspondence: hugo.deboer@ebc.uu.se

† Contributed equally

'Department of Systematic Biology, Uppsala University, Norbyvägen 18D, SE-

75236 Uppsala, Sweden

Full list of author information is available at the end of the article
}

and during the postpartum period care should be taken to restore the mother to equilibrium [1]. Confinement as a treatment involves staying inside and near heat, washing only with hot water, drinking hot drinks, eating hot food, and staying away from drafts [1]. Confinement as a term is fairly broad and can include steam sauna and bathing, mother roasting and hotbeds, dietary proscriptions and consumption of medicinal plant decoctions.

Pregnancy, parturition and the postpartum period are not without risk to the mother and infant. According to the latest data, the infant mortality rate (deaths per 1000

\section{() Biomed Central}


live births) and maternal mortality (maternal deaths per 100000 live births) for Laos is 60.3 and 660, respectively $[2,3]$. By comparison, those numbers for Sweden are 3.2 and $3[2,3]$. Maternal mortality occurs mainly during the first week postpartum, and the main causes in East Asia and the Pacific area are in order of mortality: haemorrhage, sepsis/infections, obstructed labor and hypertensive diseases [4].

Steam sauna and bath is common throughout Southeast Asia (for review see [1]), and often involve making a decoction of medicinal plants. The participant may either take a bath directly as is common for the Yao in Laos, Thailand and Yunnan province, China [5-7], sit in a special room into which steam from the decoction is led $[1,8]$, or sit in a tent-like construction with $[9,10]$, or on a seat-less chair over [11], a pot containing the steaming decoction. By lifting the lid of the pot the steam is let out, along with the essential oils and other volatile substances, for inhalation and absorption through the skin, and as the water cools off the mother uses the decoction to cleanse her body.

Mother roasting is culturally related to steam baths, but differs in that the convalescent individual lies on a bed placed above a brazier with charcoal embers on which aromatic plants are laid, thus enabling the essential oils to vaporize. Mother roasting is often done to 'dry out', cease expulsion of lochia, restore the uterus to its pre-pregnancy condition and to alleviate postpartum abdominal pain [1]. The hotbed is also an opportunity to rest, to stay away from daily chores and to strengthen social relations [12]. Mother roasting seems to be confined to Southeast Asia, where it is widespread and reported from Borneo [13], Laos [10,14,15], Malaysia [16], Myanmar [17], the Philippines [18], Thailand [19] and Vietnam [20].

In Laos, postpartum practices and food restrictions are common, and a recent study reports that of women in the capital Vientiane, 93\% reported adopting a restricted diet after delivery ('phit kam'), and 97\% lay on hot beds of embers ('yu phai') for a period of an average of two weeks [12]. The hotbed is believed to help to dry up and heal the vagina and uterus, and to relax muscles and decrease pain, and noncompliance is regarded as having negative consequences on both maternal and child health [21]. Modern healthcare associates the hotbed with causing maternal and infant death, poor lactation, and diarrhea [12].

Mother roasting and steam baths involve the use of medicinal plants [5,7,9-11]. In mother roasting ('yang phai') and hot bed therapy ('yu phai' or 'yu kam') the plant material is placed on the bed, or directly on the charcoal brazier; in steam baths the plant material is decocted, and the water is used for bathing or applied to the skin for cleansing; and in steam saunas the plant material is placed in hot or boiling water, and the convalescent is placed in a confined area saturated with steam, and subsequently washes herself with the decoction. In all procedures the convalescent is exposed to volatile oils from the plant material through inhalation and topical application. Specific plant species used medicinally in traditional steam saunas and baths have been reported $[7,10,11,22]$, whereas reports on plant species used in mother roasting are few $[10,19]$.

Essential oils are used widely to prevent and treat human disease [23]. Antimicrobial efficacy of essential oils from many plant species against a whole range of organisms has been reported [23,24]; and inhalation of essential oils or their individual volatile terpenes is known to have a significant role in controlling the central nervous system [23].

This study aims to 1) survey and identify the most salient plant species used in postpartum mother roasting and steam sauna in Laos; 2) analyze the main constituents of the essential oils of these species using GC-MS; and 3) evaluate the traditional use of these species in postpartum recovery based on their chemical constituents.

\section{Methods}

\subsection{Interviews}

Semi-structured interviews were conducted from 2005 to 2010 in 15 villages in Nakai District, Khammouane Province, and at the steam saunas at Wat Nakhoun Noy monastery, Naxay Thong District; Vientiane Prefecture and Wat Sop Pa Luang, Vientiane city; Vientiane Prefecture, Lao People's Democratic Republic. A total of more than 65 interviews was conducted with people belonging to 4 ethnic groups: the Lao, Saek, Brou, and Kry Phong. Village group interviews, which were culturally most acceptable, were carried out by female interviewers with female informants, and included the village midwife and mothers (women with 1 or more children). Individual interviews between female informants and interviewers were carried out at the two monasteries in Vientiane Prefecture. The traditions and rituals for delivery, mother roasting, steam sauna and bathing were documented and triangulated through multiple interviews and directed questions concerning details, construction, species, temperatures, volumes, times and periods. The interviews used free listing of medicinal plants per usage (mother roasting, steam sauna, bathing) to elicit information. All interviews were conducted in the homestead; and at the end an informal open-ended interview was conducted to collect individual information of each informant. In general the interviews lasted around 3-4 hours, depending on the informants' knowledge as well as the number of assisting interpreters. During the interviews ethno-botanical information was gathered about 
the plants' local names, uses, preparations, properties, dosages and availability.

Research permission for this study was granted by the National University of Laos (NUoL), within the bilateral research collaboration framework between Sida-SAREC and NUoL, regulated additionally through a Memorandum of Understanding between Uppsala University (UU) and NUoL. Biological material was transferred between NUoL and Uppsala University following an Access and Benefit Sharing and Material Transfer Agreement signed between UU and NUoL. Prior Informed Consent was obtained from informants involved in interviews and plant collection walks. Ethical approval was not required for this study as research participants were only interviewed on knowledge of plant species used for medicinal purposes. Participants were not subjected to any treatment, were not part of any clinical trials, and no information is presented here that could identify individual participants.

\subsection{Plant material}

Following the interviews, plant material for herbarium vouchers was collected in the surrounding forest with some of the informants. All herbarium vouchers were deposited and identified at the herbarium of the National University of Laos; duplicates were deposited at the herbaria UPS and E. The following herbarium vouchers were associated with the plant material used for GC-MS analysis: VL2112, Amomum villosum Lour., Vientiane province, Vangvieng district, Ban Houay Mor Neua, N $18^{\circ}$ 48' 28.6', E $102^{\circ} 31^{\prime} 36.7$ ', alt $291 \mathrm{~m}$. Vichith Lamxay et al. 17 Jan. 2010; VL2079, Amomum villosum Lour., Champasak province, Paksong district, Bane Kong Ta Youn, N 15 $25^{\prime}$ 55.2”, E $106^{\circ} 22^{\prime} 38.5^{\prime}$, alt 1003 m., Vichith Lamxay et al. 26 Aug. 2009. VL 2059, Amomum microcarpum C.F.Liang \& D.Fang, Oudomxay province, $\mathrm{Na}$ Mor district, Ban Nam Pheng, N 2100' 38.1", E $101^{\circ}$ 39' 50.8", alt. 737 m., Vichith Lamxay et al. 19 Aug. 2009.

\subsection{Essential oils}

Fresh plant material was collected in the field together with herbarium vouchers, and the essential oils were extracted in situ using steam distillation. Fresh plant material was placed with 2 liters distilled water in a 5 liter round-bottomed flask, connected to a steam distillation column, and heated using a heating mantle or open charcoal fire. Local tap water was used for the condenser, and was left to run, or circulated using a $12 \mathrm{~V}$ pump in case no running water was available. The essential oils were collected and stored in sealable $2 \mathrm{ml}$ labeled vials.

\subsection{Chemical analysis}

GC-MS analysis was performed at the Sarawak Biodiversity Centre, Kuching, Sarawak, Malaysia. Essential oils were analyzed using GC-MS to identify their components. GC-MS was performed using an Agilent $6890 \mathrm{~N}$ gas chromatograph, directly coupled to an Agilent 5975B mass selective detector (MSD) (Agilent Inc., Little Falls, USA). The column used was an HP-5MS 5\% Phenyl Methyl Siloxane capillary column $(30 \mathrm{~m} \times 0.25 \mathrm{~mm}$ $\times 0.25 \mu \mathrm{m}$ ) (Agilent Inc., Little Falls, U.S.). GC-MS operating conditions were as follows: injector temperature, $250^{\circ} \mathrm{C}$; transfer line, $240^{\circ} \mathrm{C}$; oven temperature, increasing from 60 to $240^{\circ} \mathrm{C}$ at $3^{\circ} \mathrm{C} / \mathrm{min}$; carrier gas, helium at constant flow of $1.2 \mathrm{ml} / \mathrm{min}$ at $250^{\circ} \mathrm{C}$; sample injection volume, $1 \mu \mathrm{l}$; headspace inlet glass liner, 4.0 $\mathrm{mm}$ i.d; splitless purge flow to split vent, $60 \mathrm{ml} / \mathrm{min}$ at $0.75 \mathrm{~min}$. MS acquisition parameters were as follows: full scan with scan range 40-400 amu; solvent delay: 5 min. MSD ChemStation E.02.01.1177 (Agilent Inc., Little Falls, U.S.) data acquisition software was used to compare mass spectra of chromatographic peaks with entries of Nist 08 and Wiley $8 \mathrm{n}$ databases.

\section{Results}

3.1 Postpartum medicinal plant use and GC-MS analysis of essential oil constituents

The survey of postpartum recovery customs and plant use conducted 67 interviews at 17 locations in Khammouane province and Vientiane prefecture, Lao People's Democratic Republic. The 10 species most commonly mentioned (as used by three or more ethnic groups) are reported in Table 1 including usage information on plant part, method and medicinal purpose. Most important of all plant species was the use of Amomum spp. for the steam sauna and bath, and Blumea balsamifera for mother roasting, hotbed, steam sauna and bath, and their use was reported in every single interview. B. balsamifera was available at all locations, but either Amomum microcarpum or A. villosum was used depending on local availability. Informants in Nakai district reported that $A$. microcarpum could be substituted for A. uliginosum in case of local scarcity. Gas chromatography coupled mass spectrometry (GC-MS) of essential oils of Amomum microcarpum, and A. villosum revealed that both species are rich in volatile terpenoids (Table 2). Essential oil data for B. balsamifera was collected from existing literature (Table 3).

\subsection{Confinement rituals of postpartum recovery ('yu phai' and 'yu kham')}

All informants reported postpartum recovery customs and rituals. The default place for postpartum recovery is the hotbed, where mother and infant rest during most of the day and night. The hotbed is only vacated for the following cleansing routine, which is undertaken 3 times per day: steam sauna, bath, roasting on stool or standing over fire, roasting on hotbed, followed by a return to the 
Table 1 Medicinal plants used mother roasting and steamsauna

\begin{tabular}{|c|c|c|c|c|c|c|}
\hline Scientific name & $\begin{array}{l}\text { Lao } \\
\text { name }\end{array}$ & Vouchers & Part used & Preparation & Medicinal use & Salience \\
\hline $\begin{array}{l}\text { Blumea balsamifera (L.) } \\
\text { DC. (Asteraceae) }\end{array}$ & $\mathrm{Nad}$ & $\begin{array}{l}\text { VL1751; VL 1824; Kool } \\
614\end{array}$ & $\begin{array}{l}\text { Leaves; } \\
\text { Twigs }\end{array}$ & $\begin{array}{l}\text { Steamsauna; } \\
\text { Bath; } \\
\text { Roasting }\end{array}$ & $\begin{array}{l}\text { Postpartum recovery: Anaemia (dizziness, } \\
\text { headache); Puerperal fever; Lactagogue; } \\
\text { Postpartum physical recovery; Postpartum } \\
\text { secondary haemorrhage; Perineal healing; } \\
\text { Retraction of the uterus; Miscarriage recovery }\end{array}$ & 4 \\
\hline $\begin{array}{l}\text { Amomum spp. (A. } \\
\text { villosum Lour.* and A. } \\
\text { microcarpum C.F.Liang } \\
\text { \& D.Fang**) } \\
\text { (Zingiberaceae) }\end{array}$ & $\begin{array}{l}\text { Mak } \\
\text { Naeng }\end{array}$ & $\begin{array}{l}\text { VL 2054*; VL 2064*; VL } \\
2079^{*} ; \mathrm{VL} 2112^{*} ; \mathrm{VL} \\
2055^{* *} ; \mathrm{VL} 2059^{* *} ; \mathrm{VL} \\
2076^{* *}\end{array}$ & $\begin{array}{l}\text { Leaves; } \\
\text { Pseudostems }\end{array}$ & $\begin{array}{l}\text { Steamsauna; } \\
\text { Bath }\end{array}$ & $\begin{array}{l}\text { Postpartum recovery: Anaemia (dizziness, } \\
\text { headache); Puerperal fever; Postpartum } \\
\text { secondary haemorrhage; Perineal healing; } \\
\text { Retraction of the uterus; Lactagogue }\end{array}$ & 4 \\
\hline $\begin{array}{l}\text { Citrus grandis (L.) } \\
\text { Osbeck (syn. C. maxima } \\
\text { (Burm.f.) Merr.) } \\
\text { (Rutaceae) }\end{array}$ & $\begin{array}{l}\text { Mak } \\
\text { Phouk }\end{array}$ & VL 1753; VL 1397 & Leaves & $\begin{array}{l}\text { Steamsauna; } \\
\text { Bath }\end{array}$ & $\begin{array}{l}\text { Postpartum recovery: Anaemia (dizziness, } \\
\text { headache); Puerperal fever; Lactagogue; } \\
\text { Postpartum secondary haemorrhage; Perineal } \\
\text { healing; Retraction of the uterus }\end{array}$ & 4 \\
\hline $\begin{array}{l}\text { Cymbopogon citratus } \\
\text { (DC.) Stapf (Poaceae) }\end{array}$ & SiKhay & VL 1813 & $\begin{array}{l}\text { Whole } \\
\text { plants }\end{array}$ & $\begin{array}{l}\text { Steamsauna; } \\
\text { Bath; } \\
\text { Roasting }\end{array}$ & $\begin{array}{l}\text { Postpartum recovery: Anaemia (dizziness, } \\
\text { headache); Puerperal fever; Lactagogue }\end{array}$ & 4 \\
\hline $\begin{array}{l}\text { Alpinia galanga (L.) } \\
\text { Willd. } \\
\text { (Zingiberaceae) }\end{array}$ & Kha & $\begin{array}{l}\text { VL1748; VL 1383; VL } \\
\text { 1776; VL } 1854\end{array}$ & $\begin{array}{l}\text { Leaves; } \\
\text { Pseudostems }\end{array}$ & $\begin{array}{l}\text { Steamsauna; } \\
\text { Bath }\end{array}$ & $\begin{array}{l}\text { Postpartum recovery: Anaemia (dizziness, } \\
\text { headache); Puerperal fevers; Lactagogue }\end{array}$ & 4 \\
\hline $\begin{array}{l}\text { Artocarpus heterophyllus } \\
\text { Lam. (Moraceae) }\end{array}$ & Mak Mi & VL 2125; Kool 472 & Leaves & $\begin{array}{l}\text { Steamsauna; } \\
\text { Bath }\end{array}$ & $\begin{array}{l}\text { Postpartum recovery: Anaemia (dizziness, } \\
\text { headache); Puerperal fever }\end{array}$ & 3 \\
\hline $\begin{array}{l}\text { Gigantochloa parvifolia } \\
\text { (Brandis ex Gamble) T. } \\
\text { Q. Nguyen (Poaceae) }\end{array}$ & Mai Sod & $\begin{array}{l}\text { VL 1833; VL 1742; Kool } \\
471\end{array}$ & Leaves & $\begin{array}{l}\text { Steamsauna; } \\
\text { Bath }\end{array}$ & $\begin{array}{l}\text { Postpartum recovery: Anaemia (dizziness, } \\
\text { headache); Puerperal fever; Lactagogue; } \\
\text { Postpartum mother recovery; Postpartum } \\
\text { secondary haemorrhage, Perineal healing; } \\
\text { Retraction of the uterus }\end{array}$ & 3 \\
\hline $\begin{array}{l}\text { Gonocaryum lobbianum } \\
\text { (Miers) Kurz } \\
\text { (Icacinaceae) } \\
\end{array}$ & Kanleuang & $\begin{array}{l}\text { VL 1396; VL 1424; VL } \\
\text { 1516; Kool } 470\end{array}$ & $\begin{array}{l}\text { Twigs; } \\
\text { Leaves }\end{array}$ & $\begin{array}{l}\text { Steamsauna; } \\
\text { Bath; } \\
\text { Roasting } \\
\end{array}$ & $\begin{array}{l}\text { Postpartum recovery: Anaemia (dizziness, } \\
\text { headache); Puerperal fever }\end{array}$ & 3 \\
\hline $\begin{array}{l}\text { Liquidambar formosana } \\
\text { Hance (Altingiaceae) }\end{array}$ & Somphay & $\begin{array}{l}\text { VL 1355; VL 1554; VL } \\
1808\end{array}$ & Inner bark & $\begin{array}{l}\text { Steamsauna; } \\
\text { Bath }\end{array}$ & $\begin{array}{l}\text { Postpartum recovery: Anaemia (dizziness, } \\
\text { headache); Puerperal fever }\end{array}$ & 3 \\
\hline $\begin{array}{l}\text { Phoebe lanceolata Nees } \\
\text { (Lauraceae) }\end{array}$ & Phayven & $\begin{array}{l}\text { VL 1353; VL 1511; Kool } \\
\text { 538; Kool } 619\end{array}$ & $\begin{array}{l}\text { Leaves; } \\
\text { Twigs }\end{array}$ & $\begin{array}{l}\text { Steamsauna; } \\
\text { Bath }\end{array}$ & $\begin{array}{l}\text { Postpartum recovery: Anaemia (dizziness, } \\
\text { headache); Puerperal fever; Postpartum } \\
\text { secondary haemorrhage, Perineal healing; } \\
\text { Retraction of the uterus }\end{array}$ & 3 \\
\hline
\end{tabular}

normal hotbed temperature. The remaining time is spent on the hotbed, and it is here that the mother eats, nurses and sleeps.

\subsubsection{Hotbed ('nang kham' and 'nang phai')}

The hotbed ritual commences when the mother goes into labor, and the parturient is guided to lie down on a bamboo bed in the kitchen area of the house that is covered by a pandan mat and fresh leaves of $B$. balsamifera. The bed has been prepared in advance, and either the midwife or a female close relative will have lit a charcoal fire underneath the bed. The charcoal fire is made either on an unbaked clay slab, or in a cooking brazier, and is centered directly under the pelvis. The fire is continually tended to keep both room and bed warm $\left(>50^{\circ} \mathrm{C}\right)$. After delivery the infant is washed, and both mother and infant retreat to the bed. The hotbed period lasts 14-21 days, after which the mother resumes her normal daily routine.
Hotbed is considered an essential part of postpartum recovery, and all informants strictly observed a hotbed period of at least 14 days. The medicinal qualities attributed to the hotbed practice were physical recovery, protection against puerperal fever, alleviating symptoms of postpartum anaemia (dizziness and headaches specifically), stimulating expulsion of the lochia, ceasing postpartum bleeding, perineal healing and as lactagogue.

\subsubsection{Steam sauna ('hom') and bath ('ab')}

In the steam sauna ritual the mother goes to the washing room ('san'), which in most rural Lao raised houses consists of a small annex to the kitchen lacking walls and a roof. Here she sits down on a small stool covered in fresh $B$. balsamifera leaves. In front of her are two aluminum pots, one filled with a decoction of medicinal plants and another with cold river or tap water. The core medicinal plants added to the decoction (Table 1), are added in amounts of $0.3-1.0 \mathrm{~kg}$ each to the pot, and 
Table 2 Major compounds in essential oils from fresh Amomum species

\begin{tabular}{|c|c|c|c|c|c|c|c|}
\hline & & \multicolumn{2}{|c|}{ VL2112 A. villosum } & \multicolumn{2}{|c|}{ VL2079 A. villosum } & \multicolumn{2}{|c|}{ VL2059 A. microcarpum } \\
\hline & & Leaves $(\mathrm{g})$ & Rhizome (g) & Leaves (g) & Fruit (g) & Leaves $(\mathrm{g})$ & Fruit (g) \\
\hline Chemical name & CAS number & 1000 & 780 & 1000 & 360 & 700 & 350 \\
\hline b-pinene & $127-91-3$ & 6.3 & 46.2 & 19.7 & 15.2 & 8.0 & 4.8 \\
\hline b-phellandrene & $555-10-2$ & 6.8 & - & - & - & - & - \\
\hline D-limonene & $5989-27-5$ & 8.4 & - & 8.1 & 1.2 & 4.5 & 0.4 \\
\hline L-fenchone & $1195-79-5$ & 8.9 & 4.8 & 2.7 & 2.6 & - & - \\
\hline pino-camphone & $547-60-4$ & 5.0 & - & - & - & - & - \\
\hline camphor & $76-22-2$ & - & - & 23.2 & 31.4 & - & - \\
\hline terpinen-4-ol & $562-74-3$ & 7.3 & 8.6 & 3.6 & 3.1 & - & - \\
\hline a-terpinene & $99-86-5$ & 16.1 & 1.4 & - & - & - & - \\
\hline a-terpineol & $98-55-5$ & 4.5 & 1.1 & - & - & - & - \\
\hline iso-borneol & $124-76-5$ & 3.1 & - & - & - & - & - \\
\hline linalool & $78-70-6$ & - & - & - & - & 40.4 & 25.4 \\
\hline borneol & $5655-61-8$ & - & - & 1.8 & 2.0 & 6.5 & - \\
\hline nerolidol & $7212-44-4$ & - & - & - & - & 22.3 & 49.4 \\
\hline bornylacetate & $76-49-3$ & - & - & 14.5 & 17.0 & - & - \\
\hline \multicolumn{2}{|c|}{ Fresh material oil content (\%o) } & 1.20 & 0.40 & 0.20 & 1.50 & 0.70 & 1.40 \\
\hline
\end{tabular}

heated on a brazier to $95-100^{\circ}$, and subsequently transferred to the washing room. The mother undresses, and covers herself and the pots with a thick blanket, creating a little tent. Inside she lifts the lid of the pot with the hot decoction to let out steam, and stoops to inhale the hot aromatic air. The mother underneath the blanket can be quantified as a cone of approximately 175 liters volume with the mother, the stool, and the pots taking up roughly 75 liters. The remaining 100 liters of air space is available for saturation with evaporated volatile oils. Infusion in boiling water of a volume of $<3$ kilos of fresh plant material, could lead to evaporation of 4-

Table 3 Reported compounds in essential oils from Blumea balsamifera (L.) DC. leaves

\begin{tabular}{|c|c|c|c|c|c|c|}
\hline Chemical name & $\begin{array}{l}\text { CAS } \\
\text { number }\end{array}$ & $\begin{array}{l}\text { Guenther, } 1952 \\
\text { [65] }\end{array}$ & $\begin{array}{l}\text { Roi, } 1955 \\
{[66]}\end{array}$ & $\begin{array}{l}\text { Van Duong, } 1993 \\
\text { [67] }\end{array}$ & $\begin{array}{l}\text { Truyen \& Chau, } 1999 \\
\text { [25] }\end{array}$ & $\begin{array}{l}\text { Bhuiyan et al., } 2009 \\
\text { [68] }\end{array}$ \\
\hline$\alpha$-pinene & $7785-70-8$ & & & & & 0.48 \\
\hline$\beta$-pinene & $127-91-3$ & & & & & 1.2 \\
\hline D-limonene & $5989-27-5$ & & + & + & + & 0.2 \\
\hline camphor & $76-22-2$ & 75.0 & + & + & + & 0.1 \\
\hline linalool & $78-70-6$ & & & & & 1.3 \\
\hline 1,8-cineol & $470-82-6$ & & + & + & + & \\
\hline borneol & $5655-61-8$ & 20.0 & + & 25.0 & + & 33.2 \\
\hline caryophyllene & $87-44-5$ & & & & & 8.2 \\
\hline ledol & $577-27-5$ & & & & & 7.1 \\
\hline phytol & $7541-49-3$ & & & & & 4.6 \\
\hline $\begin{array}{l}\text { caryophyllene } \\
\text { oxide }\end{array}$ & $1139-30-6$ & & & & & 4.1 \\
\hline myrcene & $84776-26-1$ & & & + & & \\
\hline$\beta$-camphene & $5794-03-6$ & & & + & & \\
\hline$\beta$-eudesmol & $473-15-4$ & & & + & & \\
\hline$\gamma$-eudesmol & $1209-71-8$ & & & & & 3.2 \\
\hline guaiol & $489-86-1$ & & & & & 3.4 \\
\hline thujopsene & $470-40-6$ & & & & & 4.4 \\
\hline \multicolumn{2}{|c|}{ Fresh material oil content (\%) } & n.s. & n.s. & 0.50 & $0.2-1.88$ & 0.40 \\
\hline
\end{tabular}


$20 \mathrm{ml}$ of essential oils (Table 2 and Table 3). Fresh plant material is added to the water when the essential oils have evaporated. The resulting concentrations of evaporated essential oils are possibly high enough to induce physiological effects, either through inhalation or dermal condensation on infected or inflamed perineal areas.

After 20-30 minutes, the mother opens the other pot and mixes the cold water with the hot medicinal decoction to create a mixture at $50-60^{\circ} \mathrm{C}$. She then proceeds to cleanse her entire body by splashing hot water from a dipper over her body and washing herself. The cleansing takes 10-15 minutes, and when done the mother wraps herself in a sarong without drying, and goes into the house for mother roasting.

\subsubsection{Mother roasting ('yang phai')}

Mother roasting, the practice where the mother exposes herself to high temperatures $\left(80-100^{\circ} \mathrm{C}\right)$ over hot charcoal embers is done in three different ways: while seated on a chair, while standing crouched over the fire, and while reclining on the bed. In all cases the fire is usually cooled down prior to roasting by putting coarse salt on the embers. The first two practices are interchangeable and done immediately after steam sauna and bathing, and always followed by mother roasting on the bed.

In mother roasting on a chair the mother is seated on an open rattan stool covered in fresh $B$. balsamifera leaves, and a brazier with hot embers is placed underneath at a distance of $20-30 \mathrm{~cm}$ from the perineum. In mother roasting over the fire the mother stands spread and slightly crouched over the fire exposing the vagina. In both practices the mother is wrapped in a thick cloth, and remains over the brazier for 10-30 minutes. The purpose of the treatments is reportedly to dry the body and specifically the vagina after the bath, and prevent contamination from the use of towels.

Mother roasting on the bed is similar to the standard hotbed procedure. In this case, however, the fire under the bed is used differently. Instead of being used to keep the mother warm while lying with her infant on the bed (hotbed), in the case of mother roasting it is stoked hot for a medicinal treatment lasting 20-30 minutes, during which the infant is passed to a family member. During mother roasting fresh leaves of Blumea balsamifera (L.) DC., Cymbopogon citratus (DC.) Stapf, and/or Gonocaryum lobbianum (Miers) Kurz are placed on the bed and the convalescent mother lies on them covered by a cotton blanket. C. citratus and G. lobbianum are used seldom as substitutes of $B$. balsamifera in case of unavailability. Volatile oils are vaporized from the leaves by the heat of the fire and confined underneath the blanket, thus surrounding the mother lying on the bed. The mother inhales essential oil vapors and her skin is both in direct contact with fresh plant material and intensively exposed to the vapors confined under the blanket.

\section{Discussion}

\subsection{Blumea balsamifera}

B. balsamifera is rich in essential oils with an oil content of $0.2-1.88 \%$ of fresh weight [25]. Here it is reported in postpartum recovery to treat anaemia related afflictions such as dizziness and headache. In addition it is used to treat puerperal fever, serve as a lactagogue, alleviate postpartum secondary haemorrhage, promote perineal healing and retraction of the uterus. It is also used to aid perineal healing and retraction of the uterus during miscarriage recovery. In previous studies it is reported in the treatment of leucorrhea, migraine [26]; for conditions after childbirth [27]; and for postpartum recovery [10].

Its main constituents are borneol and camphor (Table $3)$, both of which show strong in vitro antibacterial activity [28]. In addition, mixtures of camphor and borneol isolated from other species show inhibitory effects towards several microorganisms, possibly resulting from synergistic interactions $[29,30]$. Camphor is used in Chinese and Japanese traditional medicine as analgesic and is very common in balms and liniments for external use.

Puerperal fever resulting from microbial infections is frequent, and maternal and neonatal death from Streptococcus infections is known to occur [10]. B. balsamifera is used during all stages of the hotbed and steam sauna procedure as a way of reducing microbial infections. The use of B. balsamifera in the steam sauna, bath and hotbed procedure seems highly relevant for antimicrobial and hygienic purposes.

Its traditional use reported here also involves pain relief, and borneol has demonstrated analgesic effects related to a positive modulating effect of GABA receptors [31]. Analgesic effects of camphor could be due to camphor-induced desensitization of TRPV1 receptors as well as the blocking of TRPA1 receptors [32].

In addition to antimicrobial and analgesic properties, borneol has documented anticoagulant properties [33], which in turn could be a risk factor in traditional use of B. balsamifera to stop postpartum bleeding. Excess bleeding is not uncommon following childbirth in rural areas in Laos [10]. Some reservations about the possible analgesic and anticoagulant effect concern the uncertainty on actual uptake in this form of treatment. However receptor-activated responses can be effective also at low doses.

\subsection{Amomum species}

All Amomum species are rich in essential oils, and many are used in traditional medicine in Southeast Asia for a range of ailments. Informants in this study reported the use of Amomum spp. in postpartum recovery to treat anaemia related afflictions such as dizziness and headache. In addition it is used to treat puerperal fever, 
serve as a lactagogue, alleviate postpartum secondary haemorrhage, promote perineal healing and retraction of the uterus. In previous studies Amomum spp. are reported as emmenagogue; to treat uterine tumors; to ease childbirth, and to promote postpartum recovery [34]. Bonifacy [35] indicates that A. villosum is a traditional medicine for treating troubles in pregnancy and various abdominal ills. In Cambodia, a decoction of the rhizome of $A$. villosum is considered to improve the blood circulation, and is used as a tonic given to women after childbirth [36]. A. microcarpum is used by the Brou, Saek and Kry in postpartum recovery [10], but no other use is reported in scientific literature. In this study Brou, Saek and Kry Phong informants reported the postpartum use of $A$. microcarpum specifically, and indicated that the leaves and/or fruit are used in steam sauna and baths.

\subsubsection{Amomum villosum}

The analyzed samples of $A$. villosum show a great variation in terpene spectrum with $\beta$-pinene, camphor, bornyl acetate, terpinen-4-ol, fenchone, D-limonene, $\alpha$ terpinene as the major compounds, but with substantial variation per voucher and plant part (Table 2).

$\beta$-pinene has antimicrobial activity, which is possibly accentuated through synergistic effects with other terpene constituents like 1,8-cineol [37], borneol or linalool. Minor components like $\beta$-pinene and for the whole plant oil terpineol might support an antimicrobial effect [38].

Camphor is used in Chinese and Japanese traditional medicine as analgesic and is very common in balm and liniments for external use. Camphor shows strong in vitro antibacterial activity [28], and mixtures of camphor and borneol isolated from other species show inhibitory effects towards several microorganisms, possibly resulting from synergistic interactions [29,30]. Analgesic effects of camphor could be due to camphor-induced desensitization of TRPV1 receptors as well as the blocking of TRPA1 receptors [32].

Research on bornyl acetate from A. villosum in mice has shown it to have analgesic effects [39], and inhalation has sedative effects [40]. Other interesting data show that bornyl acetate has an antiabortive effect on pregnant mice through modulation of the immunological balance at the maternal-fetal interface [41]. However, in the studied ethnic groups steam sauna is used first after birth, and whether inhalation or transdermal uptake of bornyl acetate has any beneficial effects to the convalescing mother remains unclear.

Terpinen-4-ol is diuretic [42], which corroborates the traditional use of $A$. villosum seeds during pregnancy dysuria in Vietnam [25]. In addition, Terpinen-4-ol shows strong in-vivo inhibitory effects on growth of Candida albicans in rat vaginal candadiasis [43]. The doses studied are however higher than could be expected in the steam sauna treatment. Nevertheless synergistic effects could strengthen the activity. Terpinen-4-ol has also been shown to have anti-inflammatory effects by suppressing production of inflammatory mediator factors TNFalpha, IL-1beta, IL-8, IL-10 and PGE2 [44]. In addition, terpinen-4-ol has also been shown to have in vitro antiviral activity [45]. Terpinen-4-ol and $\alpha$-terpinene are the main constituents of the essential oil of Melaleuca alternifolia (Maiden \& Betche) Cheel, which has antimicrobial and anti-inflammatory properties supported by a wealth of in vitro data [46], and some clinical data [47]. $\alpha$-Terpinene in addition is widespread in plant essential oils, and has good antioxidative properties [48].

Fenchone has acute local analgesic effects [49] in an in vitro frog model. Fenchone is also effective as pesticide [50-52] through inhibition of acetylcholinesterase activity [53].

D-limonene exhibits antimicrobial activity like many other terpenes and is a key ingredient in many antimicrobial essential oils [54]. The antimicrobial effect is due to a terpene-induced disturbance of microbial membranes [55]. D-limonene has low human toxicity, and in humans it has been used in humans to treat heartburn due to its gastric acid neutralizing effect; and has confirmed chemopreventive activity against breast and colorectal cancer [56].

\subsubsection{Amomum microcarpum}

The main components in the essential oil of $A$. microcarpum are linalool, nerolidol and $\beta$-pinene, with the leaves containing significant amounts of borneol and Dlimonene. The latter and $\beta$-pinene have been discussed above.

Several linalool accumulating species are used in traditional medicine. Linalool has a dose-dependent sedative effect on the central nervous system, and hypnotic, anticonvulsant and hypothermic properties are also reported [57]. Park et al. [58] report an in vitro anti-fungal effect. Linalool has also been shown to have an antinociceptive effect, resulting in possible pain reduction [59]. Linalool has acute local analgesic effects from low doses [49] in an in vitro frog model.

Nerolidol arrests and or inhibits growth of parasites such as Plasmodium falciparum [60], Babesia spp. [61] and Leishmania spp. [62] Nerolidol has also been demonstrated to sensitize Staphylococcus aureus and Escherichia coli to antibiotics [63]. During the steam bath this sensitization could result in synergistic effects with antimicrobial compounds such as camphor, bornyl acetate, D-limonene, terpinen-4-ol and $\alpha$-terpinene.

\section{Conclusions}

\subsection{Hotbed and mother roasting}

$B$. balsamifera is the main species used in hotbed and mother roasting, whereas the other two reported species, 
C. citratus and G. lobbianum have only minor roles as substitutes. During hotbed and mother roasting the mother is lying in constant direct skin contact with leaves of $B$. balsamifera, which are heated from below at $50-70^{\circ} \mathrm{C}$ for hotbed, and $90-100^{\circ} \mathrm{C}$ for mother roasting. Evaporation and subsequent inhalation of volatile oils is especially intensive in mother roasting: not only are the leaves strongly heated from below, but also the mother is completely covered by a blanket. Although evaporation and inhalation of volatile oils during mother roasting may be effective, it is not likely to prevent the ailments ascribed to benefit from mother roasting. The main functional role of covering the bed in B. balsamifera is likely to be sanitary, since maintaining a high standard of hygiene in the homestead and hotbed is difficult. Covering the bed in fresh leaves exhibiting strong antimicrobial activity [28-30] is an effective way of overcoming this challenge. Hygiene is augmented by frequent steam saunas and baths (2-6 times per day), and refreshing the leaves on the bed prior to each mother roasting.

\subsection{Steam sauna and bath}

Evaporation of 4-20 ml of essential oils of B. balsamifera and Amomum spp. during the steam sauna procedure would result in high concentrations of components like camphor, bornyl acetate, borneol, D-limonene, linalool, nerolidol, fenchone, terpinen-4-ol and $\alpha$-terpinene. Although vapors of linalool, terpinen-4-ol and $\alpha$-terpinene have been shown to have antimicrobial effects on airborne microbes [38], inhalation is not likely to have a significant role in alleviating the ailments reported by the convalescing mothers.

During the steam bath following the steam sauna the mother cleanses the perineum with the medicinal plant infusion. This cleansing is done with the hot water used in the preceding steam sauna. The water cools off during the treatment, rendering the temperature too low for the volatile terpenoids to evaporate. Consequently it is rich in volatile oils and other plant secondary metabolites. A double-blind controlled study on the effect of postpartum episiotomy healing using sitz baths with lavender essential oil found that inflammation and pain relief were significantly improved compared to the control group using povidone-iodine sitz baths [64]. The three-times daily dermal application of the traditional medicinal plant boiled extract, rich in essential oils with documented antimicrobial activity, as is customary in postpartum recovery in Laos, is likely to improve hygiene, clean wounds and sores, and aid wound healing. Synergistic interactions between nerolidol and present terpenes, like camphor, bornyl acetate, D-limonene, terpinen-4-ol and $\alpha$-terpinene could enhance efficacy of these antimicrobial compounds in inhibition of pathogen growth. Pain relief through analgesic action of camphor, bornyl acetate, fenchone and linalool could alleviate discomfort from parturition wounds.

\section{Acknowledgements}

The authors wish to thank the Executive Secretariat of Nam Theun 2 Watershed Management and Protection Authority (NT2-WMPA) for facilitating field work in these remote areas; the many informants who collaborated in all aspects of this study; and the female interviewers: Douangnapha Vaiyaphanh, Fongsamouth Anoulak, and Sipaphay Keohouanghoung, who helped collect the data. VL and LB were supported by the bilateral research cooperation between SIDA and the National University of Laos funded by the Swedish International Development Cooperation Agency. HdB was supported by SIDA-SAREC grant SWE-2005338, and grants from Anna Maria Lundins stipendiefond, Helge Ax:Son Johnsons stiftelse, Regnells botaniska resestipendium, Royal Swedish Academy of Sciences stipend FOA06-258, Sernanders stiftelse, and SYNTHESYS grant GB-TAF-4255

\section{Author details}

${ }^{1}$ Department of Systematic Biology, Uppsala University, Norbyvägen 18D, SE75236 Uppsala, Sweden. ${ }^{2}$ Department of Biology, National University of Laos, Dongdok Campus, Vientiane, Lao PDR.

\section{Authors' contributions}

$H d B, V L$, and $L B$ conceived the research. $V L$ was responsible for field research and interviews. LB performed the chemical analysis. VL identified the herbarium vouchers; $\mathrm{HdB}, \mathrm{VL}$, and $\mathrm{LB}$ processed the data. $\mathrm{HdB}$ drafted the manuscript. All authors have read and approved the final manuscript.

\section{Competing interests}

The authors declare that they have no competing interests.

Received: 23 February 2011 Accepted: 15 December 2011

Published: 15 December 2011

\section{References}

1. Manderson L: Roasting, Smoking, and Dieting: Malay Confinement in Cross-Cultural Perspective. The Manner Born: Birth Rites in Cross-Cultural Perspective Walnut Creek, CA: Altamira Press; 2003, 137-159.

2. Population Division of the Department of Economic and Social Affairs of the United Nations Secretariat: World Population Prospects: The 2008 Revision Population Database. 2008.

3. World Health Organization: Maternal mortality in 2005: estimates developed by WHO, UNICEF, UNFPA, and the World Bank Geneva: WHO Press; 2007.

4. Ronsmans C, Graham WJ, others: Maternal mortality: who, when, where, and why. The Lancet 2006, 368:1189-1200.

5. Long C, Li R: Ethnobotanical studies on medicinal plants used by the Red-headed Yao people in Jinping, Yunnan Province, China. Journal of ethnopharmacology 2004, 90:389-395.

6. Srithi K, Balslev H, Wangpakapattanawong P, Srisanga P, Trisonthi C: Medicinal plant knowledge and its erosion among the Mien (Yao) in northern Thailand. Journal of Ethnopharmacology 2009, 123:335-342.

7. Li S, Long C, Liu F, Lee S, Guo Q, Li R, Liu Y: Herbs for medicinal baths among the traditional Yao communities of China. Journal of ethnopharmacology 2006, 108:59-67.

8. Lundh E: Plant Use in Ante- and Postpartum Healthcare in Lao PDR. 2007.

9. Liulan W, Nanakorn W, Fukui VN: Food and medicinal plants used for childbirth among Yunnanese Chinese in Northern Thailand. J Ethnobiol 2003, 23:209-226.

10. de Boer HJ, Lamxay V: Plants used during pregnancy, childbirth and postpartum healthcare in Lao PDR: A comparative study of the Brou, Saek and Kry ethnic groups. Journal of Ethnobiology and Ethnomedicine 2009, 5:25.

11. Zumsteg IS, Weckerle CS: Bakera, a herbal steam bath for postnatal care in Minahasa (Indonesia): Documentation of the plants used and assessment of the method. Journal of ethnopharmacology 2007, 111:641-650. 
12. Barennes $H$, Simmala C, Odermatt $P$, Thaybouavone T, Vallee J, MartinezUssel B, Newton PN, Strobel M: Postpartum traditions and nutrition practices among urban Lao women and their infants in Vientiane, Lao PDR. European journal of clinical nutrition 2009, 63:323-331.

13. Jensen E: Iban birth. Folk 1966, 8:165.

14. Spire C: Les laotiens, coutumes, hygiène, pratiques médicales Challamel; 1907.

15. Halpern J: Laos Health Problems Los Angeles, CA: University of Los Angeles; 1961.

16. Manderson L: Pregnancy, Confinement and Menstruation Food Beliefs in Peninsular Malaysia. 1979.

17. Nash M: The golden road to modernity: village life in contemporary Burma New York; 1965.

18. Hart DV: From pregnancy through birth in a Bisayan Filipino village. In Southeast Asian Birth Customs: Three Studies in Human Reproduction. Edited by: Hart DV, Rajadhon PA, Coughlin RJ. New Haven, NJ: HRAF Press; 1965:65-71.

19. Hanks JR: Maternity and its rituals in Bang Chan. Bijdragen tot de Taal-, Land-en Volkenkunde 1966, 122:289.

20. Coughlin RJ: Pregnancy and birth in Vietnam. In Southeast Asian Birth Customs: Three Studies in Human Reproduction. Edited by: Hart DV, Rajadhon PA, Coughlin RJ. New Haven, NJ: HRAF Press; 1965:209-68.

21. Pottier R: In Sante et Societe au Laos (1973-78) Edited by: Paris Comite de Cooperation avec le Laos 1978

22. Lamxay V, de Boer HJ, Björk L: Traditions and plant use during pregnancy, childbirth and postpartum recovery by the Kry ethnic group in Lao PDR. Journal of Ethnobiology and Ethnomedicine 2011, 7:14.

23. Edris AE: Pharmaceutical and therapeutic potentials of essential oils and their individual volatile constituents: a review. Phytotherapy Research 2007, 21:308-323.

24. de Boer HJ, Kool A, Broberg A, Mziray WR, Hedberg I, Levenfors JJ: Antifungal and anti-bacterial activity of some herbal remedies from Tanzania. Journal of ethnopharmacology 2005, 96:461-469.

25. Truyen LV, Chau NG: In Selected Medicinal Plants in Vietnam. Volume 1. Hanoi, Vietnam: Science and Technology Publishing House; 1999.

26. Petelot A: Les plantes médicinales du Cambodge, du Laos et du Vietnam Saigon: Centre de Recherches Scientifiques et Techniques, Impr. d'ExtrêmeOrient; 1952

27. Burkill IH, Haniff M: Malay Village Medicine. The Gardens' Bulletin, Straits Settlements 1930, 6:165-321.

28. Dorman HJD, Deans SG: Antimicrobial agents from plants: antibacterial activity of plant volatile oils. Journal of Applied Microbiology 2000, 88:308-316.

29. Kelen M, Tepe B: Chemical composition, antioxidant and antimicrobial properties of the essential oils of three Salvia species from Turkish flora. Bioresource technology 2008, 99:4096-4104

30. Polatoglu K, Demirci F, Demirci B, Gören N, Can Baser KH: Antimicrobial Activity and Essential Oil Composition of a New T. argyrophyllum (C. Koch) Tvzel var. argyrophyllum Chemotype. Journal of Oleo Science 2010, 59:307-313.

31. Granger RE, Campbell EL, Johnston GA: (+)-And (-)-borneol: efficacious positive modulators of GABA action at human recombinant [alpha] 1 [beta] 2 [gamma] 2L GABAA receptors. Biochemical pharmacology 2005, 69:1101-1111.

32. Xu H, Blair NT, Clapham DE: Camphor activates and strongly desensitizes the transient receptor potential vanilloid subtype 1 channel in a vanilloid-independent mechanism. Journal of Neuroscience 2005, 25:8924.

33. Li YH, Sun XP, Zhang YQ, Wang NS: The antithrombotic effect of borneol related to its anticoagulant property. The American Journal of Chinese Medicine 2008, 36:719-727.

34. Perry LM, Metzger J: Medicinal plants of East and Southeast Asia: attributed properties and uses MIT press Cambridge, MA; 1980.

35. Bonifacy: Notes sur la plante et la fruit appeles "Sa-nhon" [Amomum villosum Lour.]. Bull Econ Indochine 1913, 16:929-931.

36. Dy Phon P: Dictionnaire des Plantes Utilisees au Cambodge Phnom Penh: Olympic; 2000

37. Van Zyla RL, Seatlholof ST, Van Vuuren SF, Viljoen A: Pharmacological interactions of essential oil constituents on the viability of microorganisms. Natural product communications 2010, 5:1381.

38. Sato K, Krist S, Buchbauer G: Antimicrobial effect of vapours of geraniol, (R)-(-)-linalool, terpineol, terpinene and 1,8-cineole on airborne microbes using an airwasher. Flavour and Fragrance Journal 2007, 22:435-437.
39. Wu X, Xiao F, Zhang Z, Li X, Xu Z: Research on the analgesic effect and mechanism of bornyl acetate in volatile oil from amomum villosum. Zhong yao cai = Zhongyaocai $=$ Journal of Chinese medicinal materials 2005, 28:505.

40. Buchbauer $G$, Jäger $W$, Jirovetz $L$, Meyer F, Dietrich H: Effects of valerian root oil, borneol, isoborneol, bornyl acetate and isobornyl acetate on the motility of laboratory animals (mice) after inhalation. Die Pharmazie 1992, 47:620-622.

41. Wang X, Ma A, Shi W, Geng M, Zhong X, Zhao Y: Quercetin and Bornyl Acetate Regulate T-Lymphocyte Subsets and INF-y/L-4 Ratio In Utero in Pregnant Mice. Evidence-Based Complementary and Alternative Medicine 2011, 2011:7.

42. ESCOP: Monograph Juniperi Pseudo Fructus. ESCOP Monographs: The Scientific Foundation for Herbal Medicinal Products, 2 2003, 1:283.

43. Mondello F, De Bernardis F, Girolamo A, Cassone A, Salvatore G: In vivo activity of terpinen-4-ol, the main bioactive component of Melaleuca alternifolia Cheel(tea tree) oil against azole-susceptible and-resistant human pathogenic Candida species. BMC infectious diseases 2006, 6:158.

44. Hart PH, Brand C, Carson CF, Riley TV, Prager RH, Finlay-Jones JJ: Terpinen4-ol, the main component of the essential oil of Melaleuca alternifolia (tea tree oil), suppresses inflammatory mediator production by activated human monocytes. Inflammation Research 2000, 49:619-626.

45. Garozzo A, Timpanaro R, Bisignano B, Furneri PM, Bisignano G, Castro A: In vitro antiviral activity of Melaleuca alternifolia essential oil. Letters in applied microbiology 2009, 49:806-808.

46. Carson CF, Hammer KA, Riley TV: Melaleuca alternifolia (tea tree) oil: a review of antimicrobial and other medicinal properties. Clinical microbiology reviews 2006, 19:50.

47. Hammer KA, Carson CF, Riley TV, Nielsen JB: A review of the toxicity of Melaleuca alternifolia (tea tree) oil. Food and chemical toxicology 2006, 44:616-625.

48. Li GX, Liu ZQ: Unusual antioxidant behavior of a- and y-terpinene in protecting methyl linoleate, DNA, and erythrocyte. Journal of agricultural and food chemistry 2009, 57:3943-3948.

49. Zalachoras I, Kagiava A, Vokou D, Theophilidis G: Assessing the Local Anesthetic Effect of Five Essential Oil Constituents. Planta medica 2010, 76:1647-1653.

50. Lee HS: Acaricidal activity of constituents identified in Foeniculum vulgare fruit oil against Dermatophagoides spp.(Acari: Pyroglyphidae). $J$ Agric Food Chem 2004, 52:2887-2889.

51. Abdelgaleil SA: Molluscicidal and insecticidal potential of monoterpenes on the white garden snail, Theba pisana (Muller) and the cotton leafworm, Spodoptera littoralis (Boisduval). Applied Entomology and Zoology 2010, 45:425-433.

52. Nukenine EN, Adler C, Reichmuth C: Bioactivity of fenchone and Plectranthus glandulosus oil against Prostephanus truncatus and two strains of Sitophilus zeamais. Journal of Applied Entomology 2010, 134:132-141

53. López MD, Pascual-Villalobos MJ: Mode of inhibition of acetylcholinesterase by monoterpenoids and implications for pest control. Industrial Crops and Products 2010, 31:284-288.

54. Soković M, Glamočlija J, Marin PD, Brkić D, Griensven LJL: Antibacterial Effects of the Essential Oils of Commonly Consumed Medicinal Herbs Using an In Vitro Model. Molecules 2010, 15:7532-7546.

55. Di Pasqua R, Betts G, Hoskins N, Edwards M, Ercolini D, Mauriello G: Membrane toxicity of antimicrobial compounds from essential oils. $J$ Agric Food Chem 2007, 55:4863-4870.

56. Sun J: D-Limonene: safety and clinical applications. Alternative Medicine Review 2007, 12:259.

57. Elisabetsky E, Marschner J, Onofre Souza D: Effects of linalool on glutamatergic system in the rat cerebral cortex. Neurochemical research 1995, 20:461-465.

58. Park MJ, Gwak KS, Yang I, Kim KW, Jeung EB, Chang JW, Choi IG: Effect of citral, eugenol, nerolidol and [alpha]-terpineol on the ultrastructural changes of Trichophyton mentagrophytes. Fitoterapia 2009, 80:290-296.

59. Peana AT, De Montis MG, Nieddu E, Spano MT, D'Aquila PS, Pippia P: Profile of spinal and supra-spinal antinociception of (-)-linalool. European journal of pharmacology 2004, 485:165-174.

60. Rodrigues Goulart H, Kimura EA, Peres VJ, Couto AS, Aquino Duarte FA, Katzin AM: Terpenes arrest parasite development and inhibit 
biosynthesis of isoprenoids in Plasmodium falciparum. Antimicrobial agents and chemotherapy 2004, 48:2502.

61. Aboulaila M, Sivakumar T, Yokoyama N, Igarashi I: Inhibitory effect of terpene nerolidol on the growth of Babesia parasites. Parasitology International 2010, 59:278-282.

62. Arruda DC, D'Alexandri FL, Katzin AM, Uliana SR: Antileishmanial activity of the terpene nerolidol. Antimicrobial agents and chemotherapy 2005, 49:1679.

63. Brehm-Stecher BF, Johnson EA: Sensitization of Staphylococcus aureus and Escherichia coli to antibiotics by the sesquiterpenoids nerolidol, farnesol, bisabolol, and apritone. Antimicrobial agents and chemotherapy 2003, 47:3357.

64. Vakilian K, Atarha M, Bekhradi R, Chaman R: Healing advantages of lavender essential oil during episiotomy recovery: A clinical trial. Complementary Therapies in Clinical Practice 2010.

65. Guenther E: Oil of Blumea balsamifera. In The Essential Oils. Volume 5. New York, USA: Van Nostrand; 1948:431-433.

66. Roi J: Traité des plantes médicinales chinoises. Encycl. Biol. 47 P. Lechevalier, Paris; 1955.

67. Van Duong N: Medicinal Plants of Vietnam, Cambodia and Laos Hanoi, Vietnam: Mekong Printing; 1993.

68. Bhuiyan MN, Chowdhury JU, Begum J: Chemical components in volatile oil from Blumea balsamifera (L.) DC. Bangladesh Journal of Botany 2009, 38:107-109.

\section{Pre-publication history}

The pre-publication history for this paper can be accessed here: http://www.biomedcentral.com/1472-6882/11/128/prepub

doi:10.1186/1472-6882-11-128

Cite this article as: de Boer et al:: Steam sauna and mother roasting in Lao PDR: practices and chemical constituents of essential oils of plant species used in postpartum recovery. BMC Complementary and Alternative Medicine 2011 11:128.

\section{Submit your next manuscript to BioMed Central and take full advantage of:}

- Convenient online submission

- Thorough peer review

- No space constraints or color figure charges

- Immediate publication on acceptance

- Inclusion in PubMed, CAS, Scopus and Google Scholar

- Research which is freely available for redistribution

Submit your manuscript at www.biomedcentral.com/submit 